\title{
EL «DESORDENADO EMPUJE DEL FRENTE POPULAR». MOVILIZACIÓN Y VIOLENCIA POLÍTICA TRAS LAS ELECCIONES DE 1936
}

\author{
Mobilization and political violence following the \\ Spanish general elections of 1936
}

\author{
MANUEL ÁLVAREZ TARDÍO \\ Universidad Rey Juan Carlos \\ manuel.tardio@urjc.es
}

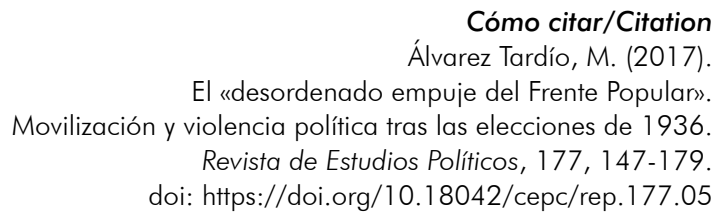

Resumen

Este artículo presenta los resultados de una pormenorizada investigación, basada principalmente en fuentes primarias, sobre las características de la movilización política que se produjo en los días posteriores al cambio de Gobierno, tras las decisivas elecciones generales de 1936 en la España de la Segunda República. Su objetivo principal es contribuir a una más y mejor fundamentada comprensión del papel que desempeñó la violencia política, analizando su presencia e impacto. Se ha optado por centrar el estudio en el contexto trascendental en el que se produjo el traspaso de poderes después de las elecciones para poder así, dentro de un período corto, reconstruir de forma detallada esa violencia. Además, de forma más específica, este artículo proporciona una respuesta a un interrogante importante: en qué medida el cambio repentino de Gobierno contribuyó a la desmovilización de los grupos radicalizados.

\section{Palabras clave}

Violencia política; democracia; España; historia; siglo xx; Segunda República; Frente Popular. 


\begin{abstract}
This paper provides the results of a detailed investigation, mainly based on primary sources, regarding the characteristics of the political mobilization that followed the decisive Spanish general elections of 1936. This mobilization occurred five months before the Civil War, during the last period of the Second Republic. The main objective of the paper is to contribute to a richer and better-informed understanding of the role played by political violence, by analyzing its presence and impact. It studies the specific circumstances in which the transfer of powers took place after the elections. The paper focuses on a short period of time, allowing a detailed analysis of events. In addition, this paper provides an answer to an important question: did the sudden change of government contribute to the demobilization of the extremist groups during this period?
\end{abstract}

\title{
Keywords
}

Political violence; Democracy; Spain; History; 20th Century; Second Spanish Republic; Popular Front. 


\section{SUMARIO}

I. INTRODUCCIÓN. II. IRSE PARA PACIFICAR. III. LA «GENTE SUELTA POR LAS CALLES». IV. TRAS LA «HUIDA». V. EL ALCANCE DE LA VIOLENCIA. VI. QUÉ HACER CON LAS «CHAMUSQUINAS». VII. APUNTE FINAL. BIBLIOGRAFÍA.

\section{INTRODUCCIÓN'}

Muchos regímenes democráticos no lograron sobrevivir a la ola de poder dictatorial que se expandió por Europa desde comienzos de la década de 1920. Uno de los que corrió peor suerte fue la Segunda República española. Al poco de cumplir cinco años, en el verano de 1936, un golpe de Estado interrumpió su consolidación. Este artículo se propone contribuir a un conocimiento más preciso de la historia política de la etapa comprendida entre febrero y julio de 1936. Se ha escogido un período fundamental para seguir profundizando en la investigación de la compleja relación entre la movilización social y la violencia política durante la Segunda República: el análisis del contexto en el que se produjo el traspaso de poderes y el cambio de Gobierno poco después de las elecciones generales de 1936. El ámbito cronológico es muy breve - básicamente los días 18 a 21 de febrero-, pero eso está justificado porque hasta ahora no se ha procesado y analizado con suficiente detenimiento la información primaria disponible, que es mucho más pormenorizada y rica de lo que se ha dado por supuesto. Es, además, una información que arroja mucha luz sobre las condiciones políticas y sociales en las que se realizó el inesperado relevo en el Gobierno el mediodía del 19 de febrero, y que nos permite analizar cuáles fueron las implicaciones en términos de violencia política y respuesta de las autoridades ${ }^{2}$. Y dentro de ese objetivo general, este artículo quiere

1 Este artículo, enviado a la Revista de Estudios Políticos en junio de 2016, se inscribe en el proyecto de investigación con referencia HAR2015-65115-P (MINECO/FEDER).

2 El estudio clásico de Tusell (1971) sobre las elecciones de 1936 no incluyó un análisis de la violencia política en los días posteriores a la consulta. Otros estudios disponibles sobre la violencia en la primavera de ese año han pasado muy de puntillas por las jornadas inmediatamente posteriores a las elecciones. Al respecto, véanse, sobre todo, Cibrián (1978), Payne (2005), Cruz (2006), Ranzato (2014) o González Calleja (2015). A estos habría que añadir algunos estudios de orden regional, en general mucho más precisos y pegados a la evidencia empírica que los anteriores; entre otros, 
aportar evidencias empíricas para formular una respuesta mejor documentada sobre el siguiente interrogante: en qué medida la llegada repentina de un nuevo ejecutivo presidido por la izquierda republicana y cuando todavía estaba en marcha el escrutinio, facilitó la desmovilización de los grupos más radicalizados de la coalición del Frente Popular; o bien, por el contrario, el protagonismo de estos últimos, lejos de moderarse, perduró e influyó en la acción del primero.

El estudio de la violencia política ${ }^{3}$ tiene ya un largo recorrido en la historiografía y las ciencias sociales. No es objetivo de este artículo plantear una discusión sobre las diversas corrientes y formulaciones teóricas ${ }^{4}$, que llevaría varias páginas, si bien el debate metodológico subyace a la formulación de nuestro objeto de estudio, en tanto que, como se verá, esta investigación busca arrojar luz sobre la relación entre la violencia política y el papel del Estado. Por influencia de la sociología histórica, y especialmente del enfoque tillyano, un parte de la historiografía española ha analizado esta cuestión incidiendo en la idea de que la aparición de la violencia en la España de los años treinta guardaría mucha relación con la incapacidad del Estado, en pleno proceso democratizador, para afrontar y canalizar las «acciones reivindicativas» de los grupos sociales y políticos. Como señaló tempranamente Julio Aróstegui, la llamada acción colectiva desembocaría en violencia no tanto por «la naturaleza de la actividad» como por las «fuerzas» implicadas y, «en particular», el «cómo respondan las autoridades». También ha tenido cierta

hay espacio para el análisis de la violencia, aunque ya en la primavera, en Rey Reguillo (2008), Gil Andrés (2006), Requena (2006), Chaves Palacios (2000), Sepúlveda Losa (2003), Macarro (2000) o Barragán-Lancharro (2006).

3 Por lo referido al concepto de violencia política, esta investigación se ciñe a la propuesta formulada por Botz (1982: 300) en su estudio sobre el caso austriaco. Para él, constituían violencia política todas aquellas «acciones en las que los seres humanos infligen (de forma contundente) daño físico — heridas o muerte- unos sobre otros». Es decir, la violencia es el "más extremo" de los métodos que pueden usarse para resolver «las formas de conflicto social y político que pueden darse en una sociedad». Esa violencia se encuentra no solo en el «área» propiamente dicha de la disputa política —las instituciones, las elecciones y los partidos - sino que "está ligada» de forma precisa a muchos otros ámbitos del conflicto como el laboral o el económico. Para Botz, finalmente, la violencia política no solo incluye la considerada ilegal sino también la violencia que ejerce el Estado a través de los agentes del orden.

4 Entre otros, algunos títulos fundamentales del debate científico sobre la violencia política son: Nieburg (1969), Von Der Mehden (1973), Graham y Gurr (1983), Mommsen y Hirschfeld (1982), Della Porta (2006), Conteh-Morgan (2003), Tilly (2007) y Kalyvas (2010). 
influencia, dentro de esa corriente, la premisa del sociólogo Michael Mann según la cual el mayor peso de la violencia se habría producido en aquellos casos nacionales en los que, por lo incipiente de la democratización, los Estados habrían mantenido «intactos muchos aspectos de los poderes estatales del antiguo régimen», viviéndose así una situación de «estado dual» en el que las actitudes autoritarias mantendrían un elevado peso en la gestión estatal de la movilización social ${ }^{5}$. Sin embargo, otros historiadores han insistido en que un exceso de generalizaciones sobre la relación Estado, policía, violencia y movilización distorsionan el estudio del fenómeno de la violencia política, y que los datos para algunos períodos de los años treinta no confirman la hipótesis de que la acción estatal fuera el detonante principal de la violencia más mortífera, sino que habría que ponerla en relación con los discursos políticos, los partidos, las circunstancias sociales o la fortaleza o debilidad de las instituciones $^{6}$. Por nuestra parte, este artículo no presupone la validez o falsedad de ninguno de esos planteamientos, sino que busca, mediante un análisis empírico deliberadamente profuso, aportar una información más detallada para el análisis de los episodios de violencia y su relación con la gestión gubernativa del orden público, partiendo de la indiscutible, pero no siempre asumida, estructura de complejidad que rodea esas acciones y devolviendo, además, a las mismas a su contexto concreto, por naturaleza cambiante y circunstancial. En ese sentido, como explicó el sociólogo político Juan José Linz, "el estudio de la violencia política y social» es un aspecto "central», aunque no el único, para el análisis del nacimiento, consolidación y quiebra de las democracias de entreguerras. $Y$ ese estudio de la violencia requiere, incluso para el ordenado y honesto desarrollo de toda discusión teórica y metodológica, la profundización en el conocimiento pormenorizado de los episodios y características de la violencia en sus respectivos contextos políticos y sociales. $Y$ es que, como ha insistido Juan Pablo Fusi, la evidencia empírica nunca está de más, al contrario, todo lo que se diga, sea más o menos deudor de un enfoque teórico u otro, tiene que poder ser probado a partir de datos precisos y sólidos ${ }^{7}$. Y en el caso de la violencia política, siguiendo a un especialista tan reputado como Stathis Kalyvas, cualquier estudio «ha de afrontar el espinoso

5 Tilly (2007: 46), Aróstegui (1994: 47), Mann (2004: 354). En el terreno de la discusión cuantitativa sobre víctimas, véase los estudios más generales de Cibrián (1978), Payne (1990), Blázquez Miguel (2009) y González Calleja (2015).

6 Rey Reguillo (2007 y 2011), Álvarez Tardío (2012). En cuanto a la discusión de algunas generalizaciones sobre el papel de las policías, véanse Blaney (2007) y Palacios (2011).

7 Linz (1996: 35). Sobre la contribución historiográfica de Fusi y su defensa del empirismo, véase Ugarte y González (2016). 
problema de los datos», lo que incluye superar el problema, demasiado habitual, de que esos datos tienden a estar "faltos de contexto", es decir, desprovistos de «información sobre las circunstancias exactas que rodean la violencia (quién, dónde, cuándo, cómo, por quién)». ${ }^{8}$

\section{IRSE PARA PACIFICAR}

La noche posterior al cierre de los colegios electorales, la del domingo 16 al lunes 17 de febrero, no fue muy descansada para el presidente del Consejo de Ministros, el centrista Manuel Portela Valladares. El presidente de la República, Niceto Alcalá-Zamora, tuvo con él una «breve» entrevista y le encontró con el ánimo decaído. Todavía faltaban tres días hasta la reunión de las Juntas electorales provinciales y era muy pronto para que ni siquiera el Ministerio de la Gobernación pudiera tener datos significativos de la marcha del escrutinio, salvo en algunas zonas urbanas. Sin embargo, Portela sí sabía ya que los porcentajes de sus candidatos no estaban siendo los esperados y que el resultado global iba a ser apretado, descartándose una victoria electoral clara de las candidaturas antirrevolucionarias?

El Consejo de Ministros se reunió durante la mañana del día 17, en medio de importantes presiones derivadas de la movilización que habían iniciado en las calles grupos afines al Frente Popular. No en vano, en la madrileña Puerta del Sol se produjeron concentraciones esa misma mañana y manifestaciones por distintos puntos de la ciudad en las que apareció la violencia y se realizaron cargas policiales, con el resultado de un muerto. En ese Consejo se debatió sobre una posible declaración del estado de guerra, que era una medida que podía tomarse conforme a la legalidad vigente. No obstante, Alcalá-Zamora se negó; este había sido informado sobre los preparativos iniciados en algunas provincias para declarar el estado de guerra, pero desoyó las razones que lo justificaban y lo atribuyó, simplemente, a la "campaña demagógica de Gil-Robles» y a un «lamentable exceso de celo» de algunas autoridades militares. Sin embargo, tanto él como el Gobierno sabían que había problemas de orden público en varias localidades y que, contra las propias disposiciones aprobadas por el ejecutivo en los días anteriores, se estaban celebrando concentraciones, sobre todo en los alrededores de las cárceles y frente a las sedes de los ayuntamientos y los gobiernos civiles. Alcalá-Zamora juzgó que "una declaración precipitada» del estado de guerra podría «atraer otro peligro, el de un golpe de Estado

\footnotetext{
8 Kalyvas (2010: 78-79).

9 El Sol, 18-2-1936, Alcalá-Zamora (2011: 165) y Portela (1988: 183).
} 
reaccionario», aunque reconoció que estaban «ante un grave conflicto de orden público». Por eso, finalmente solo firmó el decreto que establecía el estado de alarma, aunque proporcionó una autorización a Portela para que pudiera declarar el estado de guerra más adelante si lo juzgaba necesario ${ }^{10}$.

No es muy preciso lo que sabíamos hasta ahora sobre la sucesión de acontecimientos políticos que se produjeron en las cuarenta y ocho horas siguientes al cierre de los colegios electorales. Pero hay algunas pruebas irrefutables que apuntan a que el Ejecutivo se encontró con una situación de orden público complicada. De hecho, durante la jornada del 17 hubo varias víctimas mortales en diferentes lugares, como Zaragoza, Valencia, Cartagena, Santander, Vizcaya, Las Palmas o Cáceres. En la capital aragonesa la situación fue muy grave, con tiroteos y un muerto, llegando el gobernador a resignar el control del orden público en las autoridades militares ${ }^{11}$. Por otro lado, la movilización de grupos radicales afines a las izquierdas obreras planteaba un serio problema a un Gobierno que antes de las votaciones había prohibido las reuniones o manifestaciones públicas durante el recuento electoral, temeroso de las coacciones que pudieran producirse sobre las autoridades ${ }^{12}$. Además, en virtud del estado de alarma que fue decretado tras el Consejo de Ministros, quedaron «en suspenso el ejercicio de los derechos de reunión y manifestación». Todo esto influyó en el ánimo de Portela, pues se encontró ante la responsabilidad de asumir las consecuencias negativas que podía provocar la acción policial si se ordenaba a los agentes disolver las manifestaciones por la fuerza ${ }^{13}$.

Si bien Portela se comprometió con Alcalá-Zamora a no renunciar antes de que se proclamaran los resultados de las elecciones, es decir, como muy

10 Política, Ahora, El Heraldo y ABC, 18-2-1936. Alcalá-Zamora (2011: 166, 168-170), Portela (1988: 184). Detalles sobre problemas de orden público, en la siguiente nota.

11 Todos estos episodios se pueden seguir en Centro Documental de la Memoria Histórica (CDMH), PS-Madrid, leg. 1536 y PS-Madrid, C152, leg. 1508; Archivo Giménez Fernández (AGF), B-X/2; Archivo Histórico Provincial de Cáceres (AHPC), Gobierno Civil, Orden Público, Elecciones y Referéndum, leg. 1602. Faro de Vigo, 18-2-36, El Diario Palentino, 18-2-1936, Política, 19-2-1936, El Heraldo de Madrid, 19-2-1936, La Vanguardia, 18-2-1936, El Progreso (Lugo), 18-2-1936 y La Cruz (Tarragona), 19-2-1936.

12 Significativamente, el día 17 el director general de Seguridad se reunió con diversos dirigentes, incluido un emisario de Falange, para pedirles que hicieran lo posible para controlar a sus seguidores y evitar manifestaciones y conflictos como los producidos en las últimas horas en Madrid. El Día (Alicante), 18-2-1936, y ABC, 17-2-1936.

13 Circular n. 12. Telegrama del ministro de Gobernación a los gobernadores y responsables de orden público, 17-2-1936. En Archivo General de la Administración (AGA), Gobernación, 44/2416. 
pronto el día 21, el Gobierno no acertó a frenar la movilización y los acontecimientos se precipitaron durante la mañana del 19. Para entonces los resultados completos continuaban siendo objeto de especulaciones y se seguían publicando previsiones de número de diputados bastante dispares. Los medios del centro-izquierda republicano alertaban sobre la reacción «desleal» de los «enemigos del régimen» y el peligro de ciertos «manejos» provinciales para desvirtuar los resultados. Algo más a su izquierda se pedía abiertamente que «el plazo de la transmisión del Poder»se acortara para cumplir cuanto antes con «la voluntad nacional», y el principal periódico socialista reclamaba a grandes letras el «poder para el Frente Popular». Por su parte, en el otro extremo, las derechas monárquicas se mostraban aterradas por una pronta ocupación del Gobierno por las fuerzas frentepopulistas, que serviría, a su juicio, para «legitimar la revolución de Octubre y recompensar a los revolucionarios» ${ }^{14}$.

En las primeras horas del día 19 Alcalá-Zamora volvió a hablar con Portela y creyó convencerle de que no dimitiera. Este había confesado a GilRobles, esa misma mañana, que si no se iba pronto el poder sería asaltado por el sector revolucionario de las izquierdas. Las presiones socialistas para que hubiera un cambio rápido en el poder le abrumaban. Su ministro de la Guerra, el general Molero, relató informaciones "tranquilizadoras» sobre el peligro de un golpe militar, pero eso no compensó la opinión de un presidente sobrepasado por la presión. El líder de Izquierda Republicana, Manuel Azaña, esperaba que el presidente «demor[ara] la dimisión» porque «falta[ba] repetir la elección en algunas provincias" y "ni siquiera sab[ían] exactamente cuál e[ra] el resultado electoral, ni por tanto, qué mayoría ten[ían]». Pero Portela se manifestó tajante en una conversación telefónica con Diego Martínez Barrio: «Si se hubiera tratado de una revuelta vulgar», le dijo, «la habría reprimido sin vacilar, pero este no era el caso». Y aseguró, además, que no "estaba dispuesto» a «autorizar a que se disparase» porque eso «equivaldría a manchar la limpieza de la actuación de este Gobierno»" ${ }^{15}$.

Lo que terminó de influir en el ánimo decaído del presidente del Consejo fueron las noticias que le llegaron a mediodía del día 19 sobre la continuación de los problemas de orden público, especialmente algunos asaltos en los ayuntamientos de los alrededores de Madrid capital y el resurgimiento de

14 Politica, ABC y El Socialista, 19-2-1936.

15 Gil Robles (2006: 500- 501) y Portela (1988: 180-186 y 192-193). Azaña (1981: II, 10-11) y Alcalá-Zamora (2011: 183-184). Conversación telefónica con Martínez Barrio, en Faro de Vigo, 20-2-1936. Para el marco general del papel de Azaña esos días, véanse Juliá (2008: 376-378) y Avilés Farré (2006: 397-403). 
graves altercados en algunas cárceles, asunto este que había preocupado profundamente al Gobierno en las cuarenta y ocho horas previas. Tras un último intento de Alcalá-Zamora para evitar la marcha de Portela, poco antes de las tres de la tarde el secretario del Gobierno anunció «la dimisión irrevocable» del ejecutivo y admitió que el presidente de la República se había manifestado en contra. Había sido decisivo, aunque el portavoz del Gobierno no lo reconociera públicamente, que desde las once de la mañana Portela consideraba que la situación del orden público era "gravemente inquietante» - como les dijo poco antes a sus ministros-, entre otras cosas por sendos motines en los penales de Santoña y Bilbao, aunque también por lo que interpretaba como la debilidad de algunos de sus gobernadores civiles, caso del de La Coruña. Y él, como admitió ante Martínez Barrio, no quería cargar con la responsabilidad de una represión policial que podía ser sangrienta. En público lo dijo de forma más ambigua: a media mañana aseguró que el suyo era un Gobierno «sin autoridad moral» ${ }^{16}$.

Tras la dimisión, el presidente llevó a cabo unas rapidísimas consultas por teléfono con los líderes de los diferentes partidos. Acto seguido encargó la formación de Gobierno a Manuel Azaña. Era un procedimiento atípico, el de un Gobierno que se marchaba en pleno proceso electoral y otro nuevo que se formaba sin que ni siquiera se conociera la composición del nuevo Parlamento ni se hubiera celebrado la segunda vuelta en aquellas circunscripciones donde fuera necesario. Pero Portela no aguantó la presión y la Constitución facultaba al jefe del Estado para tomar esa decisión ${ }^{17}$.

\section{LA «GENTE SUELTA POR LAS CALLES»}

A diferencia de la opinión de sus socios electorales, Azaña pensó que no podían ser "peores» las «condiciones» para volver al Gobierno. De hecho, se encontró una situación incluso más complicada de lo que había previsto. La primera señal que le inquietó fue que Portela no le habló de casi nada durante los minutos que duró el traspaso de poderes: «Como si me entregase las llaves de un piso desalquilado», afirmó. Con esos mimbres, no es extraño que un

16 La Libertad, Ahora, Política y ABC, 20-2-1936; y El Defensor de Córdoba, 19-2-1936. Alcalá-Zamora estaba informado del «resurgir del peligro de izquierdas en la calle», véase Alcalá-Zamora (2011: 183). Conversación con Martínez Barrio, en Azaña (1981: II, 11).

$17 A B C, 19$ y 20-2-1936; El Progreso (Lugo) y Ahora, 20-2-1936; y Alcalá-Zamora (2011: 188). 
rato más tarde, a primera hora de la noche de ese día 19, el nuevo presidente declarara a los periodistas que había tranquilidad en toda España ${ }^{18}$. Por otro lado, le calmó saber que, a pesar de las difíciles circunstancias del relevo, la CEDA publicó un comunicado en el que aseguraba que «se atiene al resultado de la voluntad popular, sea cual resulte el escrutinio». Y todavía más importante, la dirección cedista había autorizado a Manuel Giménez Fernández para trasmitir a Martínez Barrio que ellos no pondrían obstáculos al nuevo Gobierno siempre que este controlara el orden y asegurara un recuento ordenado ${ }^{19}$.

Ese día Azaña cenó en casa y poco más tarde se marchó a la sede de Gobernación. Al llegar se encontró una «muchedumbre congregada en la Puerta del Sol» que celebraba el cambio pero que también exigía en tono amenazante un cumplimiento inmediato del programa del Frente Popular y coreaba duras consignas contra los gobernantes del segundo bienio. A eso de las once de la noche llegaron a su despacho varios representantes de los partidos obreros. El objetivo de su visita, como confirmó el socialista Largo Caballero ante los periodistas, fue «rogar al presidente del Consejo que vea el medio de que se ponga en libertad cuanto antes a los presos políticos, por tratarse de un problema que constituye nuestra mayor preocupación $»^{20}$.

Para ganar tiempo, Azaña prometió al dirigente socialista que la cuestión de los presos sería debatida en la primera reunión del nuevo Consejo de Ministros que se celebrara. Acto seguido, salió al balcón para gestionar, a su modo, el asunto de la concentración. Pidió a todos que se condujeran como «buenos republicanos" y que no alterasen el orden, pero anunció ya dos propósitos que iban a tener consecuencias para su gestión a corto plazo: de un lado, aseguró que el Gobierno haría "honor a los compromisos contraídos con la opinión» y que el mismo día 20 serían «repuestos todos los ayuntamientos republicanos de España»; de otro, prometió que la «primera preocupación del gobierno será obtener la amnistía ${ }^{21}$.

Cuando regresó del balcón, ya de madrugada, Azaña reconoció ante Martínez Barrio el problema de fondo: le parecía «imposible que la gente se aguant[ara] más de un mes» con el tema de la amnistía, hasta que las Cortes pudieran votarla. Pero, por otro lado, pensaba que, si optaban por respetar los plazos y procedimientos parlamentarios, saldrían «a motín por día», por lo

18 Azaña (1981: II, 11-12 y 16). Declaraciones, en Política y ABC, 20-2-1936.

19 El Progreso (Lugo), 20 y 21-2-1936, El Diario Palentino, 21-2-1936, Gil-Robles (2006: 502-503) y Tusell y Calvo (1991: 173-175).

20 ABC, Ahora y El Siglo Futuro, 20-2-1936. Azaña (1981: II, 16-17).

21 Política y El Heraldo de Madrid, 20-2-1936. 
que el decreto debía ser votado de inmediato por la Diputación Permanente de las extintas Cortes. En ese momento, Azaña ya sabía que la CEDA le apoyaría, aunque parcialmente, en la aprobación de una rápida amnistía; y necesitaba ese apoyo porque las derechas tenían mayoría en una Diputación que todavía reflejaba la composición del Parlamento anterior. El nuevo presidente pensó que la "presión de las circunstancias" (un eufemismo para reconocer abiertamente la tensión social de esas horas y el modo en que empezaba a manifestarse en forma de violencia contra las sedes y los dirigentes del segundo bienio) facilitaría la transacción de los cedistas en un tema tan delicado ${ }^{22}$.

Con todo, el Gobierno decidió ganar tiempo tomando una medida rápida que se anticipaba incluso a la decisión de la Diputación. Bien consciente ya de esa «presión» y de los problemas planteados en algunas cárceles, dio la orden al teniente fiscal del Tribunal Supremo, fiscal de la República en funciones, para que mandase a los fiscales de las Audiencias que solicitaran de inmediato «la libertad provisional de todos los que sufren prisión preventiva por delitos políticos o sociales» ${ }^{23}$.

Pero había además otro asunto delicado, el más complicado en ese momento de la tarde-noche del 19. Cuando Azaña y su nuevo ministro de Gobernación, Amós Salvador, se pusieron a trabajar, se encontraron con que "casi todos los gobernadores de Portela» habían «huido, abandonando las provincias" y que no habiendo autoridad en "casi ninguna parte», la gente andaba «suelta por las calles» y el problema de cómo se comportaran y lo que consiguieran hacer los grupos radicalizados sería difícil de gestionar. No en vano, a las pocas horas de creer que había resuelto el problema del orden en la Puerta del Sol sin usar la policía, Azaña empezó a recibir las noticias que Portela no le había querido contar: "disturbios» en algunas localidades esa misma tarde, según anotación del propio presidente, intentos de ocupar ayuntamientos por la fuerza, empezando por la provincia de Madrid, y nuevos motines en los penales. Bajo esas circunstancias, Azaña se reafirmó en la idea de que era «urgente conceder la amnistía», aun cuando sabía que eso no se correspondía con la letra del pacto electoral del Frente Popular, que hablaba expresamente de «someter» esa decisión «a las nuevas Cortes» ${ }^{24}$.

Las siguientes treinta y seis horas fueron decisivas para comprobar si el cambio de Gobierno y una primera aplicación rápida y parcial de la amnistía

\footnotetext{
Azaña (1981: II, 18).

23 Política y $A B C, 19$ y 20-2-1936.
}

24 Entrecomillados, en Azaña (1981: II, 16 y 18). Portela había tenido noticias de esos primeros asaltos a ayuntamientos en su último Consejo de Ministros. Portela (1988: 191). Sobre el pacto del Frente Popular, véase Juliá (1979). 
servían para calmar las aguas o, por el contrario, el cambio de Gobierno incentivaba las concentraciones y, con ellas, los desórdenes. Para empezar, el ministro Amós Salvador se enfrentó a una primera tarea urgente. Tuvo que ponerse a nombrar apresuradamente nuevos gobernadores y a exigir a los que todavía estaban en sus puestos que no se marcharan. Una circular enviada desde Madrid el día 19 muestra la complejidad de la situación heredada tras el naufragio de la nave portelista: «espero del patriotismo de V.E.», decía el ministro a los gobernadores, que "permanezca en su puesto hasta que sea sustituido, con la misma Autoridad de siempre y manteniendo con más cuidado que nunca el orden público» ${ }^{25}$.

Y es que al menos desde el mediodía del 19, esto es, desde el momento que se empezó a saber que el Gobierno de Portela estaba en crisis, algunos gobernadores habían empezado a abandonar a toda prisa sus destinos, en algunos casos por temor a las represalias de quienes se concentraban en las calles y en otros intimidados por representantes de los vencedores. Así, los de Huelva o Málaga dimitieron tras recibir una visita de los candidatos de izquierdas y pese a las órdenes contrarias de Madrid. En casi toda Andalucía pasó lo mismo. El de Almería se marchó precipitadamente nada más conocer la salida de Portela, dejando el Gobierno Civil vacío; esa misma noche un grupo liderado por el jefe local de Izquierda Republicana ocupó el edificio y tomó el poder. En algunas provincias influyó la tensión en torno al recuento de los votos. Este fue el caso de Tenerife, donde los candidatos del Frente Popular pidieron al gobernador que se fuera. Este empezó resistiéndose, pero acabó cediendo tras pasar un rato escuchando gritos a favor de su dimisión y advertencias de los dirigentes obreros sobre las consecuencias de que siguiera en su puesto. Horas más tarde se iniciaría una huelga general y el nuevo Gobierno respondería tomando medidas equiparables al estado de guerra. En Cáceres también se dejó notar la tensión relacionada con el recuento electoral: un concejal socialista de la capital, Juan Guillén, se hizo cargo del Gobierno Civil, cesando de inmediato al secretario que estaba al cargo, todo esto en medio de rumores que atribuían estos rápidos movimientos al control de las cajas que contenían las actas electorales ${ }^{26}$.

No todos los gobernadores se vieron en esas «circunstancias», si bien en Galicia, que había sido una zona especialmente conflictiva durante la campaña

25 AGA, Gobernación, 44/2416.

26 El Socialista, Ahora, El Progreso (Lugo), El Defensor de Córdoba, Faro de Vigo, El Sol y El Heraldo de Madrid, 20-2-1936; Política y La Prensa (Santa Cruz de Tenerife), 19 y 20-2-1936; El Pensamiento Alavés, 21-2-1936; El Día de Palencia y La Crónica Meridional (Almería), 20 y 21-2-1936. 
electoral, se vivieron hechos similares ${ }^{27}$. Una situación grave se dio en La Coruña: en la mañana del día 19, todavía con Portela en el poder, se formaron manifestaciones de izquierdistas en actitud desafiante ante los centros oficiales. La tensión fue en aumento y personas de pueblos cercanos se desplazaron a la capital, formándose una concentración más multitudinaria por la tarde. Conocida ya la salida de Portela, un «enorme gentío» marchó desde la Casa del Pueblo hasta la plaza donde estaba el Gobierno Civil. La mayor parte de los comerciantes empezaron a cerrar sus negocios. En ese contexto, el gobernador, desobedeciendo órdenes de Madrid y «alarmado ante la situación, resignó el mando en dos diputados electos de izquierda y dos ciudadanos del Comité de enlace de las fuerzas republicanas y socialistas». Poco más tarde un grupo de manifestantes se dirigió a la sede del ayuntamiento y repuso al alcalde cesado en octubre de 1934, mientras otros compañeros intentaban izar una bandera roja en el balcón del consistorio. Entre tanto, en ese contexto hizo acto de presencia la violencia anticlerical, produciéndose varios intentos de incendio en los templos de la ciudad ${ }^{28}$.

En general, tras conocerse la renuncia de Portela y la llegada de Azaña al Gobierno, la presencia de simpatizantes del Frente Popular en las calles fue bastante generalizada por todo el país ${ }^{29}$. Aunque algunos salieran a celebrar una victoria electoral que daban por descontada, aun cuando todavía no fuera oficial, esa movilización fue instrumentalizada para iniciar una presión política sobre el nuevo Gobierno, exigiendo cambios inmediatos en la composición de los gobiernos locales y la sustitución de las autoridades provinciales. Además, hubo muchas manifestaciones pidiendo la libertad de los presos, algunas frente a las cárceles, esperando una excarcelación inmediata. Y en la medida en que los grupos coaligados en el Frente Popular empezaban a recuperar los resortes del poder, las concentraciones también sirvieron para presentar una nueva exigencia: la anulación de las elecciones en aquellos sitios donde el recuento del voto inclinaba la balanza hacia las derechas. Y es que lo ocurrido en La Coruña no fue un hecho excepcional.

Aunque descrito muy sumariamente, este es el contexto en el que hay que valorar los datos sobre violencia política desde mediodía del 19 hasta bien avanzado el 20. No puede decirse, ni mucho menos, que hubo una violencia

27 Álvarez Tardío (2013: 475).

28

ABC, El Socialista, Política y El Sol, 20-1-1936. Violencia anticlerical, en CDMH, PS-Madrid, C152, leg. 1508, AGF, B-X/2 y Archivo Secreto Vaticano (ASV), Nunz. Madrid, b 945.

29 Manifestaciones, en El Sol y $A B C, 20-2-1936$, El Progreso (Lugo), 21-2-1936, y El Heraldo de Madrid, 20-2-1936. 
distribuida de forma homogénea por toda la península, como se verá. No obstante, tampoco fueron hechos aislados. Se ha afirmado que con el traspaso de poderes a Azaña se "consiguió de hecho devolver la normalidad al país durante varias semanas ${ }^{30}$. Sin embargo, con los datos que se exponen a continuación, habría que puntualizar que esa "normalidad" no fue tal y que, como había previsto Azaña, la mera salida de Portela y la sensación de que el Frente Popular había vuelto al poder tuvieron consecuencias inesperadas.

\section{TRAS LA «HUIDA»}

En las dos grandes ciudades, Madrid y Barcelona, no se produjo una espiral imparable de violencia en los dos días posteriores a la salida de Portela. La principal razón es que se adoptaron amplias medidas policiales de forma preventiva. Con todo, en Barcelona hubo algunas concentraciones tras las que se produjeron altercados y enfrentamientos con los guardias de asalto, resultando un muerto. Desde última hora del 19, la Ciudad Condal estuvo literalmente blindada por la policía ante el temor de que se produjera un asalto a la cárcel para liberar a los presos. Y hubo una multitudinaria concentración proamnistía la tarde del 20, durante la cual el gobernador apaciguó los ánimos asegurando que la amnistía sería aprobada en breve por la Diputación Permanente. Entre tanto, algunos individuos aprovecharon la confusión para incendiar dos iglesias ${ }^{31}$.

Ciertamente, que las ciudades de Madrid y Barcelona no destacaran por la conflictividad no es indicativo de una calma general. De hecho, el análisis pormenorizado de las fuentes muestra que el uso de la violencia durante las movilizaciones aumentó en el paso del día 19 al 20. Hubo un incremento de la conflictividad en la región andaluza, pero los problemas se extendieron a regiones que habían permanecido relativamente tranquilas durante la campaña electoral. Las categorías más habituales de los sucesos de esos días fueron estas cuatro: ocupaciones violentas de ayuntamientos, intentos de asalto a las cárceles, ataques a edificios religiosos y agresiones a dirigentes de los partidos de centro-derecha y derecha.

Durante las primeras horas posteriores a la llegada de Azaña al poder se produjeron, sobre todo, concentraciones en las calles. En principio su finalidad

30 Ranzato (2006: 244).

31 Ahora, 21-2-1936. ASV, Nunz. Madrid, b 945 y b 912B, fasc. 3. CDMH, PS-Madrid, C152, leg. 1508. Durgan (1996: 411). El Diario Palentino, 21-2-1936, Faro de Vigo y El Defensor de Córdoba, 22-2-1936, Heraldo de Zamora y ABC, 20-2-1936. 
básica era celebrar lo que se consideraba la consumación del triunfo electoral, esto es, el relevo en el poder. Por eso se repitieron en todas ellas parecidas muestras de júbilo. Sin embargo, en muchos casos se apreció de inmediato que muchos participantes tenían otros planes: primero, redirigir a los manifestantes hacia los centros de poder local y provincial para propiciar un cambio rápido de autoridades, usando para ello todo tipo de coacciones verbales y físicas; y segundo, presionar de diversos modos para propiciar una amnistía inmediata. De este modo, la tarde del 19 fue de grave agitación en muchos puntos del país, como pudieron comprobar Azaña y el ministro Salvador en cuanto tomaron posesión. En Zamora, por ejemplo, una manifestación presidida por representantes socialistas rodeó el ayuntamiento mientras se celebraba un pleno; al poco rato se consiguió que el presidente de la gestora cediera el poder al anterior alcalde de elección popular ${ }^{32}$. En Córdoba, aprovechando que el gobernador, Antonio Cardero, se había ido, una manifestación se presentó frente el ayuntamiento en actitud violenta. Poco después, un grupo ocupó el edificio consistorial, provocando destrozos; todo esto sin presencia de agentes de seguridad. Poco antes, en la Casa del Pueblo, representantes de los partidos de izquierdas eligieron al socialista Sánchez Badajoz como nuevo alcalde. Ya en la casa consistorial, pese al intento del diputado electo de Izquierda Republicana, Antonio Jaén Morente, de hacer cumplir las órdenes del Gobierno y dejar el ayuntamiento en manos de los concejales destituidos en 1934, la "multitud» que ocupaba el edificio confirmó como nuevo alcalde al mencionado socialista. $\mathrm{Y}$ algo parecido ocurrió en otros pueblos de la provincia cordobesa, como Lucena o Peñarroya, donde también se tomó posesión de los ayuntamientos contraviniendo las órdenes gubernativas de reponer en sus puestos a los concejales de elección popular ${ }^{33}$. Especialmente graves fueron los sucesos de Palma del Río, donde algunos grupos asaltaron las sedes de la CEDA y el Partido Radical, saquearon un molino y una fábrica, destruyeron documentación del archivo municipal, provocaron graves destrozos en iglesias y conventos y expulsaron a varias monjas de sus casas. Y los problemas se prolongaron al día siguiente, ante la inacción de los agentes de la Guardia Civil, que recibieron órdenes de no actuar ${ }^{34}$.

32 Heraldo de Zamora y Ahora, 20-2-1936. El Pensamiento Alavés y El Progreso (Lugo), 20 y 21-2-1936. ASV, Nunz. Madrid, b 912B.

33 Guión, 21-2-1936, El Defensor de Córdoba, 20, 21 y 22-2-1936, El Heraldo, 21-21936.

34 Versión oficial, en CDMH, PS-Madrid, 1536 y PS-Madrid, C152, leg. 1508. Relato muy pormenorizado, en El Defensor de Córdoba, 20-2-1936. Pasividad de los guardias, en Macarro (2000: 402-403) y Moreno Gómez (1983: 353-356). Información local, en Archivo Municipal de Palma del Río, «Documentación referida al proceso seguido 
Lo de Zamora y Córdoba, por poner dos provincias muy alejadas geográficamente, no fueron hechos excepcionales. Algo parecido pasó en otras localidades nada más saberse que Portela se había ido. En Palma de Mallorca, un grupo de "comunistas y sindicalistas" se manifestó delante del ayuntamiento exigiendo que el poder municipal pasara a manos de representantes del Frente Popular; «unos cuantos» llegaron a asaltar el edificio e intervino entonces la Guardia Civil, con el resultado de dos heridos de bala. En Granada, la tarde del 20 tomaron posesión del ayuntamiento concejales socialistas en un ambiente similar: el edificio consistorial había sido ocupado por «cientos de obreros». Una situación parecida se vivió en Cádiz, Almería o Calahorra. Y en Almadén, después de que los concejales de izquierdas se hicieran con el control del ayuntamiento durante la madrugada, una manifestación que reclamaba «la jornada de cuatro horas y media» terminó frente al ayuntamiento, desde cuyos balcones escucharon al presidente del Sindicato Minero; acto seguido se produjo el asalto al local de Acción Popular en la localidad ${ }^{35}$.

La movilización y tensión de la tarde del 19 no fue un relámpago fulminante y puntual sino el preludio de una actividad más generalizada a lo largo de la jornada del 20. El primer y más importante foco de conflicto que hubo de gestionar Amós Salvador fueron las prisiones. Cuando Portela presentó la dimisión ya conocía que la situación en los penales de las provincias de Murcia, Santander o Vizcaya era muy delicada. Pero, sobre todo, la llama había prendido hacia la una de la tarde del 19 en la cárcel de Larrinaga, en Bilbao, con un «violento incendio» ${ }^{36}$. El presidente saliente supuso que la situación se calmaría con su marcha, pero no fue así exactamente. Con las noticias de su caída se propagaron los motines, encontrándose Azaña con que a última hora de la noche del 19 había serios problemas en varias cárceles. Tan serios que, en Chinchilla, tras una revuelta en protesta porque el nuevo Gobierno no daba la orden inmediata de liberación de los presos, hubo un enfrentamiento entre reclusos y guardias, así como varios intentos de fuga, con el resultado de un muerto entre los primeros. No menos complicadas fueron esas horas en otras prisiones por la impaciencia que provocó entre los presos la idea de que el cambio de Gobierno era sinónimo de inmediata liberación. En Gijón o San

por el levantamiento producido en la ciudad en los días 19 y 20 de febrero de 1936", cit. en Zamora Cano (2010: 572-573). También hay referencias en Alcalá-Zamora (2011: 207), AGF, B-X/2 y ASV, Nunz. Madrid, b 912B.

35 CDMH, PS-Madrid, 1536; ASV, Nunz. Madrid, b945; AGF, B-X/2; El Pensamiento Alavés y Diario de Almería, 20-2-1936; La Crónica Meridional (Almería) y El Heraldo de Madrid, 21-2-1936. Almadén, en Rey Reguillo (2008: 522).

36 CDMH, PS-Madrid, leg. 1536, ASV, Nunz. Madrid, b 912B, La Región (Santander) y $A B C, 20-2-1936$. 
Sebastián, tras horas de tensión y enfrentamientos que provocaron varios heridos de gravedad, a última hora de la noche empezaban a salir los presos a la calle: más de 150 en el primero y unos 60 en el segundo ${ }^{37}$.

Siendo tensa la situación en algunos penales, más complejo, desde el punto de vista de la gestión del orden público, fue lo que pasó con algunas manifestaciones del día 20. En varias localidades se reprodujeron patrones similares: concentraciones que increpaban a los dirigentes de las derechas y del Partido Radical, llegando en varios casos a asaltar sus sedes, o bien a provocar destrozos o incendios en edificios religiosos, sedes patronales o círculos agrarios. En algunos casos los episodios de violencia se manifestaron de forma muy intensa. Uno de los más ilustrativos fue el de Elche, que duró varias horas. Los ánimos habían estado muy excitados en toda la provincia de Alicante desde que se cerraron los colegios electorales. Para mayor preocupación del nuevo ministro Salvador, el gobernador abandonó su puesto a toda prisa. $\mathrm{Al}$ mando quedó de forma interina un líder local de la izquierda republicana que vio cómo la presión popular provocaba una rápida reposición de ayuntamientos durante el día 20, incluido el de Elche. En este caso, al mediodía, mientras tomaba posesión del Gobierno local el antiguo alcalde socialista, y sin que se atrevieran a comparecer los concejales derechistas, una manifestación recorrió la localidad, produciéndose incidentes verbales y altercados. Fue en ese contexto cuando un teniente de la Guardia de Asalto hizo varios disparos y provocó algunos heridos. Los socialistas locales atribuyeron a este episodio la violencia posterior en la ciudad. Sin embargo, la documentación del sumario judicial añade algunos datos relevantes: antes de que el agente disparara se había iniciado ya el asalto al Círculo de los republicanos radicales; y cuando aquel usó su arma estaba rodeado por los asaltantes, que previamente se habían negado a deponer su actitud y atacado a otros agentes. En todo caso, antes y después de ese suceso y durante las horas siguientes, ocurrieron lo que un historiador local ha llamado «los disturbios más graves de todo el período republicano» en la localidad de Elche. Los grupos radicalizados que protagonizaron la violencia siguieron una pauta observada en otros lugares: primero el asalto de las sedes de los lerrouxistas, los agrarios y los conservadores; segundo, la destrucción del Juzgado Municipal, el centro de Acción Cívica de la Mujer, la Cámara de la Propiedad Urbana; y, finalmente, el ataque a algunas casas particulares y el ritual incendiario en las iglesias de Santa María, El Salvador y San Juan, además de los conventos de las clarisas y el centro de la

37 Faro de Vigo, 20 y 22-2-1936, El Diario Palentino, 21-2-1936, y Azaña (1981: II, 18). Sepúlveda Losa (2003: 9), que sigue el Defensor de Albacete, 20 y 21-2-1936. Véase también ASV, Nunz. Madrid, b945. 
Juventud Católica. Todas las fuentes indican que se vivió una situación de descontrol en la ciudad y que las fuerzas del orden permanecieron inactivas en los primeros y decisivos compases. Se contabilizaron dos muertos y varios heridos. Pero lo peor, para el nuevo Gobierno, es que la violencia se extendió por toda la comarca, reproduciéndose los problemas en otras localidades. Al final, el Gobierno de Azaña ordenó la movilización de una compañía del regimiento militar de Valencia para que vigilara las calles en los días siguientes ${ }^{38}$.

Sin ánimo de ser exhaustivos, sabemos que durante esas horas hubo episodios de violencia grave en localidades de las provincias de Granada, Huelva, Cádiz, Córdoba, Málaga, Sevilla, Murcia, Alicante, Ciudad Real, Madrid, Barcelona, Pontevedra, La Coruña y Burgos ${ }^{39}$. Así, el mapa de las manifestaciones más violentas se extendió especialmente por la mitad sur y el litoral mediterráneo, aunque no solo $^{40}$. En muchos casos la vanguardia de esos episodios fueron grupos organizados de socialistas y comunistas, que hicieron coincidir los asaltos y destrozos con el momento en el que compañeros suyos y representantes de la izquierda republicana recuperaban el mando de los ayuntamientos y de las diputaciones. Las localidades donde los problemas se prolongaron durante más tiempo y con más virulencia fueron las siguientes: en Cartagena, se incendió la sede cedista y el nuevo alcalde, un empleado de Correos vinculado a la Casa del Pueblo, animó las acciones de represalia contra los derechistas. En Murcia, se destruyó el Círculo Tradicionalista, se incendió la sede del periódico cedista La Verdad y se asaltaron los talleres de Levante Agrario, todo esto sin que durante ese tiempo interviniera la policía. Hubo varios heridos y un muerto. En Alicante también hubo varias víctimas, dos de ellas fallecidas. Allí fueron destruidos varios locales de los republicanos radicales y centristas, así como las sedes de la Derecha Regional Agraria,

38 CDMH, PS-Madrid, leg. 1536 y PS-Madrid, C152, leg. 1508; ABC, 20-2-1936; El Defensor de Córdoba, 22-2-1936; Heraldo de Zamora, 27-2-1936, y ABC, 24-2-1936. Un análisis detallado, con los datos del sumario judicial, en Martínez Leal (2005: 139153). Documentación varia, incluido el detallado informe del administrador apostólico de Orihuela, de 24-2-1936, y la carta del obispo, Juan de Dios Ponce, al nuncio, 3-3-1936, en ASV, Nunz. Madrid, b 912.

39 A continuación, solamente las referencias de algunos casos importantes que no se comentan más abajo: Castrojeriz, Alcalá de Henares, Ciudad Real, Ronda, Melilla y Monistrol de Monserrat, en CDMH, PS-Madrid, 1536, ASV, Nunz. Madrid, b945 y b912B, AGF, B-X/2, Diario de Burgos, 24-2-1936, El Progreso (Lugo), 21-2-1936, Eco de Cartagena, 20-2-1936 y Rey Reguillo (2008: 522).

40 Esas mismas zonas fueron también las más conflictivas en momentos anteriores de la República. Véanse los mapas de causas incoadas por delitos político-sociales que se exponen en Rey Reguillo (2007: 94-97). 
el Círculo Católico y la Falange, además de causar destrozos en la imprenta del diario católico El Día. En Aguilar de la Frontera, donde unos 25 hombres armados se hicieron fuertes en la Casa del Pueblo, después de ser «totalmente saqueada» la Comunidad de Labradores e incendiados varios edificios públicos, además del local de AP y un convento. En Betanzos, grupos de izquierdistas saquearon la sede de los conservadores y apedrearon a afiliados derechistas, dirigiendo luego sus acciones contra los franciscanos y las monjas, desalojadas de sus conventos por orden del nuevo alcalde. Finalmente, en las localidades sevillanas de Carmona, Marchena o Peñaflor hubo asaltos, ocupaciones de ayuntamientos, agresiones con armas a cedistas y lerrouxistas, amén de incendios de archivos e iglesias ${ }^{41}$. Y un caso especialmente grave fue el de la localidad cordobesa de La Rambla. Varios concejales izquierdistas armados, respaldados por centenares de personas dentro y fuera del edificio consistorial, agredieron a "pedradas y tiros» a los concejales derechistas, que en este caso no se habían ausentado. Hubo seis heridos graves, todos ellos de la gestora municipal saliente, y el suceso terminó con el incendio del archivo notarial y destrozos en una iglesia. Azaña recibió un telegrama de los diputados electos por la provincia de Córdoba, Federico Fernández Castillejo y Rafael Delgado Benítez, en el que apuntaban el dato de la «inhibición» de la autoridad durante varias horas como algo determinante, aunque todavía confiaban en que las «órdenes y consejos de templanza y legalidad» que «elogiaban» en Azaña se traduciría en «urgentes y enérgicas órdenes que restablezcan la legalidad perturbada $\aleph^{42}$.

41 Aguilar, en CDMH, PS-Madrid, 1536; Guión, 25-2-1936; La Crónica Meridional (Almería), 27-2-1936; Macarro (2000: 402), y ASV, Nunz. Madrid, b 912B. Betanzos, en ASV, Nunz. Madrid, b 912B y CDMH, PS-Madrid, C152, leg. 1508. Cartagena, en Informe del vicecónsul de Cartagena al embajador Chilton, 12-3-1936, en National Archives, Foreign Office (NA-FO) 371/20520. Murcia, en CDMH, PSMadrid, leg. 1536 y PS-Madrid, C152, leg. 1508; ASV, Nunz. Madrid, b945 y 912b; AGF, B-X/2; El Pensamiento Alavés, 24-2-1936; El Día de Palencia, 21-2-1936, y La Cruz (Tarragona), 19-2-1936. Parece que también hubo problemas en la localidad cercana de Jumilla, en Alcalá-Zamora (2011: 183). Alicante, en ASV, Nunz. Madrid, b 945, fasc. 3, CDMH, PS-Madrid, 1536 y PS-Madrid, C152, leg. 1508, y Diario de Almería, 21-2-1936. También el informe confidencial de Chilton a Londres, 24-21936, en NA-FO 371/20520. Sevilla, en CDMH, PS-Madrid, leg. 1536 y PSMadrid, C152, leg. 1508; AGF, B-X/2; Macarro (2000: 403); La Cruz, 21-2-1936 (Tarragona); $A B C$ de Sevilla, 18-2-1936; y Alcalá-Zamora (2011: 207).

42 AGF, B-X/2; CDMH, PS-Madrid, 1536; Alcalá-Zamora (2011: 207); El Defensor de Córdoba, 20, 21 y 24-2-1936; Guión, 21 y 22-2-1936; y El Defensor de Córdoba, 21 2-1936. 
En general, también fueron graves los sucesos ocurridos en las capitales de provincia andaluzas, sobre todo en Málaga, Huelva, Granada y Cádiz, donde los asaltos a las sedes y los periódicos conservadores fueron acompañados de varios heridos y muertos. En Málaga, los representantes del Frente Popular ya habían presionado al gobernador para que cediera el mando, nada más empezar las primeras manifestaciones; pero eso no impidió que algunos grupos se enfrentaran a tiros con la policía y acudieran también a las casas de derechistas para apedrearlas. En Granada se repitió una escena similar, con actos de pistolerismo entre izquierdistas y derechistas. Y en Huelva, donde las manifestaciones empezaron a primera hora del 20, la violencia fue todavía mayor. Aquí, a diferencia de la anterior, los guardias permanecieron acuartelados más tiempo, durante el cual se produjeron los asaltos al Círculo Radical, a varios negocios de derechistas de la localidad y finalmente al domicilio de $\mathrm{AP}^{43}$.

En cuanto a la mitad norte del país, hubo menos episodios de violencia, si bien ese no fue el caso de las localidades gallegas de Pontevedra, Ferrol y Santiago de Compostela. En Pontevedra se asaltaron las sedes de la CEDA, Renovación y el Círculo Radical. Los guardias solo salieron a las calles después de las primeras violencias. En cuanto a Santiago y Ferrol, además de las sedes derechistas, los grupos de extremistas digirieron sus acciones contra algunos conventos y sedes de asociaciones religiosas, todo esto mientras los representantes del Frente Popular se hacían con el control de los ayuntamientos. Al igual que en la región levantina, las derechas entraron en estado de pánico en varias localidades gallegas. En Vigo, por ejemplo, empezaron a preparar una rápida salida hacia Portugal, creyendo que la revolución era inminente; incluso el vicecónsul británico de la localidad pasó por horas complicadas cuando un grupo de manifestantes estacionados delante de su casa le exigieron que izara una bandera roja en el balcón y se negó ${ }^{44}$.

Finalmente, en este balance tan apretado hay que añadir que durante esas jornadas hubo también algunos atentados vinculados a confrontaciones

43 CDMH, PS-Madrid, 1536; NA-FO 371/20520; ASV, Nunz. Madrid, b945; Macarro (2000: 403); El Pensamiento Alavés, 20-2-1936; Heraldo de Aragón, El Progreso (Lugo), El Sol y Diario de Almería, 21-2-1936; ABC, 20 y 21-2-1936; Guión, 21-2-1936; La Cruz (Tarragona), 22-2-1936; Gaceta de Tenerife, 22-1-1936; La Prensa (Santa Cruz de Tenerife), 23-2-1936; Ahora, 20 y 22-2-1936.

44 CDMH, PS-Madrid, Leg. 1536 y PS-Madrid, C152; ASV, Nunz. Madrid, b912b y b945; AGF, B-X/2; Politica y Faro de Vigo, 21-2-1936. Para la violencia en otras localidades menores de Galicia, véase CDMH, PS-Madrid, leg. 1536; y el informe del vicecónsul británico en Vigo al embajador Chilton, 26-2-1936, en NA-FO $371 / 20520$. 
previas tanto de orden estrictamente electoral como sindical. Algunos se asemejaron al más puro estilo del pistolerismo, como el que dejó muy gravemente herido al hijo de un empresario granadino o el que costó la vida a un empleado de una fábrica, tiroteado cuando se dirigía al trabajo. A veces, esos actos aparecieron en contextos de tensión y desórdenes, como ocurrió en Tenerife, donde jóvenes derechistas recibieron varios disparos. Otras se trataron de ajustes de cuentas vinculados al recuento electoral, como en el pueblo navarro de Santacara. Otros fueron durante o después de riñas políticas, por ejemplo en pueblos de Almería o de Zamora. Y hubo también agresiones a cargos políticos; uno de los más graves fue el del alcalde lerrouxista de la localidad sevillana de Fuentes de Andalucía, retenido y agredido por socialistas y comunistas, resultando con heridas de consideración ${ }^{45}$.

Por último, respecto de la actitud de los miembros de los partidos que se vieron afectados por los sucesos más graves, las fuentes indica que, en general, los cedistas y los republicanos radicales o conservadores se mostraron bastante pasivos, salvo algún caso puntual como el que ocurrió después de que manifestantes socialistas y comunistas increparan a unos jóvenes en Hoyo de Pinares $^{46}$. Se podría decir que en estos casos las fuerzas centristas y conservadoras tenían a la policía de su lado, por lo que no necesitaban responder a la violencia con más violencia. Sin embargo, pudiendo ser esto cierto en algunos casos, lo ocurrido en Elche, Huelva o Murcia muestra que en varias localidades no hubo intervención policial hasta muy avanzada la violencia, por lo que ese razonamiento no resulta satisfactorio.

Por otro lado, lo que también confirman las fuentes primarias es que un nuevo actor estaba tomando cada vez más protagonismo: los que empezaron a despuntar como vanguardia violenta en un contexto de defensa de los derechistas y la propiedad fueron los jóvenes falangistas que ya habían aparecido durante la campaña electoral previa. Fueron miembros de Falange los que intervinieron, por ejemplo, durante los graves disturbios de Murcia o en los momentos de tensión por la liberación de presos en Santander. Y recogieron, también, sus primeras víctimas mortales, como el dependiente de comercio de

45 Pistolerismo, en El Heraldo de Madrid y El Pensamiento Alavés, 21-2-1936. Santacara, en Ahora, 20-2-1936. Tenerife, en La Prensa (Santa Cruz de Tenerife), 20-2-1936. Almería, en La Crónica Meridional (Almería), 20-2-1936. Zamora, en Heraldo de Zamora, 20-2-1936. Fuentes de Andalucía, en CDMH, PS-Madrid, 1536 y La Cruz (Tarragona), 21-2-1936.

46 Hubo un muerto provocado por un afiliado al Partido Progresista que salió en defensa de los increpados. En El Socialista, 22-2-1936; ASV, Nunz. Madrid, b945; AGF, B-X/2, y El Heraldo de Madrid, 20-2-1936. 
Yecla, asesinado por socialistas el día $20^{47}$. Todas estas acciones falangistas tuvieron como respuesta la clausura inmediata de muchos de sus centros y la práctica de numerosas detenciones ${ }^{48}$.

\section{EL ALCANCE DE LA VIOLENCIA}

En los días 19 y 20 de febrero se produjeron 16 muertos y 39 heridos graves ${ }^{49}$. Además, aproximadamente 50 iglesias y casas rectorales fueron

47 La Región (Santander) y $A B C, 21-2-1936$; CDMH, PS-Madrid, leg. 1536; ASV, Nunz. Madrid, b 912B; Sanz Hoya (2006: 244) y Córdoba (2011: 216). Violencia falangista y campaña electoral, en Álvarez Tardío (2013: 477-478).

48 El día 21 y siguientes se clausuraron las sedes de Falange en Santander, Murcia, Orense o Bilbao, a veces acompañadas de detenciones. Véanse ASV, Nunz. Madrid, b 912B; La Región (Santander), 22 y 23-2-1936; Heraldo de Zamora, 26-2-1936; y El Progreso (Lugo), 26-2-1936. Sobre Falange y la "creciente violencia» a partir de marzo, véase Payne (1985: 115-116 y 119-120). Los datos que ha contabilizado González Calleja (2015: 286-287) sobre la violencia política en toda la primavera de 1936 coinciden en remarcar el especial protagonismo de Falange. También Cruz (2006: 138) apunta el «salto cualitativo en la acción violenta» de los falangistas a partir de marzo.

49 Elaboración propia a partir de las fuentes que se citan en las notas de este trabajo. Estas cifras se asemejan a las que ha publicado recientemente González Calleja (2015: 396-397) en una "Cronología de actos letales de violencia sociopolítica», si bien hay una variación significativa en número de heridos graves. Él ha constatado 19 muertos, aunque todos ellos el día 20 de febrero. La principal diferencia entre sus cálculos y mi estudio es la siguiente: él reconoce 4 muertos y 5 heridos en el motín del penal del Dueso, en Santoña, pero lo sitúa el día 17, siguiendo fuentes secundarias y especialmente a Sanz Hoya (2006: 244). Sin embargo, este último autor solo dice que fue después de la victoria del Frente Popular y su fuente es El Diario Montañés del día 20 de febrero. En mi caso, he seguido la información muy precisa del Faro de Vigo, 20 y 23-2-1936, entre otras fuentes, que sitúa los sucesos más sangrientos en el penal del Dueso la tarde del 19 y no confirma más que dos muertos en el acto y uno más a los pocos días (es decir, 3 en vez del total de 4 que señala Sanz Hoya y que recoge González Calleja). También hay una ligera discrepancia con un muerto que González Calleja computa en unos sucesos en La Rambla (Córdoba); en este caso, su única fuente es Blázquez Miguel (2009: 629). La información que yo he podido consultar no confirma esa víctima —véanse AGF, B-X/2, CDMH, PS-Madrid, 1536 ASV, Nunz Madrid, b 912B, Alcalá-Zamora (2011:207) y El Defensor de Córdoba, 21-2-1936-. Finalmente, González Calleja da por válidos entre dos y cuatro muertos que menciona el cónsul británico Hoxley en su correspondencia con el embajador, referidos a las localidades de Vigo y Villagarcía de Arosa. Yo he preferido no computarlos porque no he 
incendiadas o saqueadas, y hubo no menos de 70 asaltos, con numerosos destrozos e incendios, de sedes de partidos políticos, patronal o círculos agrarios. Todas estas cifras sugieren un contexto, el de las treinta y seis horas posteriores al relevo del Gobierno, especialmente complejo. Se podría decir, pues, que al nuevo ejecutivo se le planteó un grave problema de gestión del orden público y de contención del anhelo de revancha de sus simpatizantes, todavía en pleno recuento, lo que explicaría por qué Azaña decidió aprobar rápidamente un decreto de amnistía y dar fuerza jurídica a las ocupaciones de hecho de los ayuntamientos que se estaban produciendo.

Como hemos visto anteriormente, tanto las sedes lerrouxistas como las cedistas fueron objeto, por igual, de la acción de grupos, casi siempre jóvenes radicalizados de las izquierdas obreras ${ }^{50}$. Pese a lo que se dijo en algunos periódicos, los datos de esos sucesos no parecen confirmar una relación unívoca y recurrente entre provocaciones y acciones violentas. Hubo algo de conflictividad entre grupos rivales antes del asalto de varios centros falangistas y tradicionalistas; $y$ ya se ha mencionado el protagonismo de los seguidores de Primo de Rivera. Sin embargo, ese no fue el caso de los numerosos - mayoría en realidad — ataques a locales y periódicos de la CEDA y de los republicanos radicales. Ciertamente, tampoco era necesaria ninguna provocación porque tanto los afiliados cedistas como los lerrouxistas habían sido identificados, durante la campaña electoral, como los responsables de la «represión» de Octubre y, por tanto, eran objetivo prioritario de aquellos individuos radicalizados que identificaron victoria con venganza.

Una hipótesis apuntada en los últimos años por autores como Rafael Cruz o Eduardo González Calleja es que la existencia de víctimas en ese contexto postelectoral se debió a la acción policial, básicamente porque las cargas de los guardias de asalto o de los civiles no resolvían los problemas, sino que los exacerbaban, todo esto en momentos de máxima tensión que habrían requerido de negociación y prudencia en vez de contundencia. Los datos de que disponemos muestran, sin embargo, que la violencia de resultados trágicos tuvo poco que ver con todo eso y mucho más con la proclividad a la acción de individuos radicalizados que, casi siempre, iban armados y tenían objetivos establecidos de antemano. No quiere eso decir que los guardias de asalto o los

encontrado ninguna otra fuente que confirme esas muertes, lo que resulta extraño y aconseja tomar la información con cautela. Si sumara estos 4 muertos en Pontevedra, mi total sería de 20, frente a los 23 que presenta González Calleja (incluidos los del penal de Santoña que coloca el día 18). La fuente sobre las víctimas de Vigo que no computo es un informe de 26-2-1936, en NA-FO 371/20520.

50 Sobre los jóvenes de izquierdas y su evolución previa, véase Souto Kustrín (2004). Sobre el contexto general de la izquierda del PSOE, Juliá (1977). 
guardias civiles no provocaran víctimas al reprimir arbitraria o torpemente una manifestación, o al intentar disolver una concentración donde había mucha tensión ${ }^{51}$. Pero no hay que olvidar que hubo muchos más casos, como por ejemplo el de una pelea entre dos grupos rivales en Llanes, donde la mediación pacífica de los agentes de la guardia civil consiguió frenar la violencia antes de que hubiera víctimas graves ${ }^{52}$. Así, si bien del total de muertos de esas horas aproximadamente un $60 \%$ lo fueron por disparos de las fuerzas del orden, merece la pena detallar en qué circunstancias:

- Cuatro fallecieron en los enfrentamientos armados en las cárceles, que no habían iniciado los agentes y en los que algunos presos se comportaron de forma violenta para provocar confusión y facilitar los motines y una posible huida.

- Otro se produjo por el disparo de guardias de asalto cuando el grupo en el que estaba el fallecido intentó invadir una sede cedista en Málaga e hizo caso omiso de los primeros avisos de los agentes para que retrocedieran (el informe del gobernador de izquierdas calificaba a la víctima como «sujeto de pésimos antecedentes»).

- Algo parecido a lo anterior ocurrió con el comunista fallecido en Barcelona la tarde del 20, por disparos de los guardias, después de que un grupo de Estat Catalá se comportara de forma violenta en el transcurso de una manifestación e intentara una agresión.

- Otras dos personas murieron por balas de la Guardia Civil en un pueblo de Huelva, pero consta, como muestra la documentación de la causa abierta por ese suceso en el Tribunal Supremo, que los agentes usaron sus armas para responder a disparos previos.

- Y otras dos víctimas lo fueron por disparos de un guardia de asalto cuando intentaba detener a un grupo que había empezado el asalto y destrozo de la sede del Partido Radical en Elche, como se ha explicado anteriormente ${ }^{53}$.

51 Cruz (2006: 111) y González Calleja (2015: 286). Un balance historiográfico sobre orden público, Guardia Civil y violencia, en Blaney (2005). También, desde la perspectiva local, Carmona Obrero (2011). Y sobre la Guardia Civil: Pulido Pérez (2008). Véase también el avance de la investigación más reciente de Vaquero Martínez (2016).

52 El suceso ocurrió en Llanes la tarde del día 18. Un capitán de la Guardia Civil «apeló a la cordura de los grupos» y consiguió disolverlos después incluso de que se hubiera producido un primer disparo. El Carbayón, 19-2-1936.

53 Motines en los penales de Chinchilla y Santoña, en ASV, Nunz. Madrid, b 912B; El Diario Palentino, 21-2-1936; y Sepúlveda Losa (2003: 9). Málaga, en CDMH, PS- 
Por consiguiente, la evidencia empírica no confirma que los muertos atribuidos a las armas de las fuerzas del orden en esas horas fueran resultado de una intervención arbitraria o de una torpe gestión de la movilización de ciudadanos pacíficos. Por otra parte, el otro cuarenta por ciento de las víctimas mortales de esos dos días ocurrieron en circunstancias bastante ajenas a la policía, en algunos casos por la ausencia de aquella en vez de por su presencia. Así ocurrió en los casos ya comentados del dependiente falangista asesinado por socialistas en Yecla (Murcia) o de la socialista muerta en Hoyo de Pinares (Ávila). Otra persona fue víctima de un acto de pistolerismo, posiblemente para saldar cuentas políticas y sindicales; tres más murieron durante los graves desórdenes ocurridos en Alicante y Murcia ${ }^{54}$.

\section{QUÉ HACER CON LAS «CHAMUSQUINAS»}

La mañana del día 20, cuando se celebró el primer Consejo de Ministros tras la llegada de Azaña al poder, este tuvo ya información detallada de la situación de orden público y de los primeros actos de violencia anticlerical. "Esto me fastidia», anotó en su diario. "La irritación de las gentes va a desfogarse en iglesias y conventos, y resulta que el Gobierno republicano nace, como el 31, con chamusquinas. El resultado es deplorable. Parecen pagados por nuestros enemigos.» Esas "chamusquinas» alcanzaron proporciones notables, tanto que obligaron al Gobierno a tomar medidas para detenerlas. Así, el nuevo gobernador de Almería, Enciso Amar, de Izquierda Republicana, manifestó el día 21 que había ordenado la intensificación de la vigilancia, reconociendo implícitamente el alcance de los problemas que la prensa nacional, por mor de la censura, no estaba recogiendo ${ }^{55}$.

Los asaltos e incendios de casas rectorales, iglesias o conventos durante las primeras treinta y seis horas de vida del nuevo Gobierno fueron más abundantes allí donde se registró más violencia contra las sedes derechistas, es decir, las

Madrid, 1536; La Prensa (Santa Cruz de Tenerife), 23-2-1936; Ahora, 20 y 22-21936; y La Libertad, 20-2-1936. Huelva, en CDMH, PS-Madrid, 1536; AHN, Tribunal Supremo, Leg. 141, exp. 10; y La Prensa (Santa Cruz de Tenerife), 25-21936. Barcelona, en ASV, Nunz. Madrid, b 912B; El Diario Palentino, 21-2-1936, y Faro de Vigo, 22-2-1936. Elche, en nota 37.

54 CDMH, PS-Madrid, 1536 y PS-Madrid, C152, leg. 1508; ASV, Nunz. Madrid, b 945; AGF, B-X/2; El Pensamiento Alavés, 21 y 24-2-1936; El Heraldo de Madrid, 20-2-1936; El Socialista, 22-2-1936; El Día de Palencia y Diario de Almería, 21-21936; y Córdoba (2011: 216).

55 Azaña (1981: II, 18). Gobernador, en La Crónica Meridional (Almería), 22-2-1936. 
regiones de Andalucía, Levante y Galicia, como si hubiera una relación de dependencia entre una y otra cosa. Si en Almería la intervención de algunos vecinos y la presencia de policías malogró varios intentos de incendio en al menos cuatro edificios de la capital, no ocurrió lo mismo en otras localidades ${ }^{56}$. Con diferencia, las provincias donde más episodios de anticlericalismo hubo fueron las de Valencia, Alicante, Murcia, Málaga, Córdoba y Coruña, amén de algún otro caso aislado, por ejemplo, en localidades de Zaragoza, Salamanca, Burgos, Sevilla, Melilla o Barcelona. En muchos casos fueron grupos radicalizados los que actuaron con rapidez para asaltar y provocar incendios que resultaron muy destructivos. Así ocurrió en diferentes pueblos de Valencia, Murcia o Alicante, en contextos en los que, como se ha señalado ya, los disturbios fueron prolongados. En otros, el anticlericalismo tuvo un componente más popular, produciéndose los asaltos en medio de manifestaciones y conllevando diferentes formas de profanación, así como ocupaciones simbólicas de los templos y celebración de bailes dentro de los mismos. Así pasó en pueblos de la provincia de Málaga o de Coruña, ocurriendo también, aunque no siempre, robos y saqueos ${ }^{57}$. Para el presidente del Gobierno, toda esta violencia contra edificios religiosos era el resultado de la rapidez con que se había producido el relevo ministerial y, sobre todo, el hecho de que en algunas provincias los gobernadores se hubieran marchado precipitadamente; unos pocos, le dijo Azaña al nuncio Tedeschini, habían aprovechado para cometer "desmanes»"

El nuevo Gobierno había celebrado su primer Consejo a media mañana del día 20. El proceso electoral no había terminado todavía: en Málaga, por ejemplo, ese mismo día se estaban celebrando comicios en varias decenas de colegios y estaban en juego miles de votos; y ese día, además, tenían que reunirse

56 CDMH, PS-Madrid, 1536 y PS-Madrid, C152, leg. 1508; ASV, Nunz. Madrid, b 912B; La Crónica Meridional (Almería), 22-2-1936; y Macarro (2000: 402).

57 La relación de localidades donde se ha constatado que hubo violencia anticlerical de consecuencias graves es la siguiente: Palma del Río y Aguilar de la Frontera, en Córdoba; Casares, Estepona, Montejaque y Benaoján, en Málaga; Peñaflor, Palomares y Herrera, en Sevilla; Almusafes, Alcira, Museros, Relleu, Onteniente, Nucia, Cañamelar y El Puig, en Valencia; Torres de Berellón, en Zaragoza; Torreagüera y Beniaján, en Murcia, más la capital; Castrojeriz, en Burgos; Ferrol, Betanzos, Carranza, Serantes, Murgados y Perlío, en La Coruña, más la capital; Barcelona capital; Béjar, en Salamanca; Elche y Alicante capital; Almería capital; Melilla. Además de numerosas referencias de prensa citadas en las notas previas, véanse CDMH, PS-Madrid, C152, leg. 1508 y PS-Madrid, 1536; ASV, Nunz. Madrid, b 912B; AGF, B-X/2; Diario de Sesiones de las Cortes (DSC), 15-IV-1936; NA-FO 371/20520; y Alcalá-Zamora (2011: 207).

58 Carta de Tedeschini a Azaña, 14-III-1936, en ASV, Nunz. Madrid, b 925. 
las Juntas Provinciales del Censo para verificar, en sesión pública, la documentación y realizar el escrutinio. Cuando terminó el Consejo, a eso de las dos y media de la tarde, un portavoz del Ejecutivo anunció a la prensa la adopción de algunas medidas. La primera fue una confirmación jurídica de lo que estaba pasando ya en algunas localidades: se aprobó la reposición de todos los ayuntamientos suspendidos por decisión gubernativa. La segunda tenía importancia para la gestión de los problemas de orden en las cárceles, a la espera de aprobar la amnistía: el nombramiento de un nuevo fiscal general de la República, Alberto Paz Mateo. Junto a esto, se supo también que el presidente Azaña hablaría a la nación esa misma tarde y que el Gobierno había «estudiado un plan que permita realizar con la mayor rapidez posible los puntos del pacto base de las elecciones», lo que incluía proceder con la amnistía de inmediato. Se supo, entonces, que la fórmula escogida por el Ejecutivo sería la de someter un breve decreto a la Diputación Permanente, para no tener que esperar así a la constitución de la nueva cámara. Entretanto, se anunciaba, seguramente con la esperanza de satisfacer las expectativas de los socios electorales de la izquierda obrera, que el nuevo fiscal pediría a sus subordinados que calificaran rápidamente los delitos pendientes, lo que significaba que se podrían aprobar de inmediato numerosas libertades condicionales o prisiones atenuadas ${ }^{59}$.

En cuanto a la situación de orden, el ministro de la Gobernación anunció que la tarea más urgente, por el momento, era que los nuevos gobernadores tomaran posesión "a la mayor brevedad posible», por lo que alguna designación, como la del responsable de Valencia, se había hecho con «toda urgencia, incluso por teléfono». El mensaje era bastante claro: como el Gobierno atribuía los «desmanes» — según la expresión usada por Azaña en la entrevista con Tedeschini- a la huida de las autoridades provinciales, quería dejar claro que ese vacío de poder terminaría en breve y se tomarían las medidas policiales necesarias ${ }^{60}$.

Tal y como se había anunciado, Azaña habló por radio ese mismo día. Pidió a «todos los españoles» que cooperaran «a la obra que el Gobierno trata de emprender bajo su responsabilidad exclusiva», una obra que no tenía «ningún propósito de persecución ni de saña». Eran palabras moderadas que tranquilizaron a una parte de la opinión conservadora. Sin embargo, en privado el propio Azaña reconocía la existencia de un «desordenado empuje del Frente Popular ${ }^{61}$. No en vano, el precipitado relevo de Gobierno no había generado por sí mismo más tranquilidad en las calles, como había argumentado Portela

59 Ahora, 21-2-1936, ABC, 20 y 21-2-1936, y Política, 20-2-1936.

$60 A B C, 20-2-1936$.

61 Azaña (1981: II, 21) y Política y El Diario Palentino, 21-2-1936. 
para justificar su marcha. El ministro de Gobernación había asegurado, precisamente en la mañana del día 20, que «todo» iba «remitiendo» y que había «tranquilidad en toda España». Pero tenía información que le mostraba una situación diferente: hasta pasado el sábado 22 no empezaron a disminuir los datos sobre graves violencias, y el número de víctimas, tanto heridos como muertos, siguió aumentando. Es significativo, en ese sentido, que el mismo Amós Salvador compareciera ante la prensa en la madrugada del 20 al 21 para insistir en que el Gobierno no iba a levantar el estado de alarma por el momento ${ }^{62}$. Y es que tanto él como su presidente sabían que la situación en algunos penales y sus alrededores era muy preocupante. De hecho, Azaña habló por teléfono con Alcalá-Zamora durante esas horas y le transmitió, entre otras cosas, su «inquietud» por la evasión de presos de la cárcel de Gijón. En este penal, durante la tarde del día 20, habían salido a la calle prácticamente todos los llamados presos sociales, en un ambiente de confusión tal que también se escaparon decenas de presos comunes. Todo esto había ocurrido a la vez que se desarrollaba en los alrededores una manifestación presidida por símbolos comunistas y cánticos de la Internacional, con una destacada participación de la comunista Dolores Ibárruri, la colaboración de los candidatos socialistas y de izquierda republicana, Mariano Moreno Mateo y José Maldonado González, respectivamente. En total, abandonaron la cárcel gijonense algo más de 300 reclusos, sobre algunos de los cuales se emitieron nuevas órdenes de detención ${ }^{63}$.

\section{APUNTE FINAL}

A propósito de la movilización social ocurrida en España tras las elecciones de febrero de 1936, se ha planteado recientemente que tuvo una «dimensión de prolongación de la política pública» en la medida en que sirvió para «presionar y respaldar cambios en las instituciones derivados de la victoria electoral». Y que, a veces, se buscó «el enfrentamiento con el adversario con el fin de tomar posesión de la calle» ${ }^{64}$. Este artículo demuestra que esa presión no se produjo como resultado de la proclamación de los resultados oficiales, es decir, como fruto de una victoria electoral, sino por mor de una movilización que había empezado nada más cerrarse los colegios y que logró, primero, la dimisión de Portela y después un desbordamiento de la violencia que no era

\footnotetext{
$A B C, 21-2-1936$.

63 Alcalá-Zamora (2011: 193 y 197-198); Azaña (1981: II, 18); Ibarruri (1984: 227-233);

La Prensa (Santa Cruz de Tenerife), 22-2-1936 y CDMH, PS Barcelona, leg. 127.

64 Cruz (2006: 111).
} 
ajeno al hecho de que todavía se estaba completando el recuento y se tenían que reunir las Juntas Provinciales del Censo. Como temió Azaña, algunos grupos del Frente Popular, dentro de la izquierda obrera, entendieron que la marcha de Portela y de sus gobernadores dejaba la puerta abierta para reforzar esa presión y hacerlo de forma violenta. Estos recelaban de que el nuevo Gobierno se mostrara poco resolutivo y apelara al formalismo y la legalidad para aplazar la adopción de las medidas incluidas en el pacto del Frente Popular.

En ese sentido, la ocupación de las calles, para ellos, no se podía quedar en un simple acto de presión a favor de algún tipo de "política pública», a modo de una movilización pacífica en un entorno de democracia consolidada, sino que debía orientarse, mediante una combinación de movilización e intimidación, hacia una presión política efectiva para desbordar los cauces del formalismo democrático. Así, los datos que se recogen y analizan en este artículo muestran que la violencia política no solo no desapareció al formarse el nuevo Gobierno, sino que creció y se extendió a diversos puntos de la geografía nacional, especialmente como una forma de presionar a favor de una liberación inmediata de los presos de octubre de 1934, así como para obligar a las nuevas autoridades a tolerar una ocupación rápida $-\mathrm{y}$ muchas veces violenta- de los ayuntamientos. La evidencia empírica sobre todos esos episodios resulta, así, trascendental para comprender el alcance político de la presión de los violentos y no confundir, bajo determinadas generalizaciones y explicaciones teóricas, esa movilización coactiva con una simple celebración cívica de una victoria electoral ya descontada.

Por otro lado, esta investigación permite concluir que Portela también se equivocó al pensar que un Gobierno presidido por la izquierda republicana contaría con la ventaja de poder usar las fuerzas policiales sin que los ganadores de las elecciones lo interpretaran como una provocación, una limitación de la movilización democrática o un peligro de golpe de Estado. Azaña y su ministro de la Gobernación procuraron que las noticias del nuevo Gobierno incidieran en una recuperación de la calma, pero en privado conocieron con todo detalle que la combinación de la presión de los sectores radicalizados de la izquierda obrera, más el vacío de poder provocado por la huida de algunos gobernadores, facilitó la expansión de la violencia en algunas regiones, a la cabeza Andalucía, Levante o Galicia, pero no solo ellas. Y aunque se ha escrito que «la principal fuente de enfrentamiento fue la intervención policial» durante las manifestaciones de esos días ${ }^{65}$, es bastante probable que ni Azaña ni su ministro hubieran estado de acuerdo con esa idea así expresada, sabedores de

65 Ibid. En una línea parecida, pero referido a datos para el conjunto de la primavera de ese año, véase González Calleja (2015: 286). 
que los datos sobre la violencia de las jornadas del 19 y 20 de febrero mostraban algo que esta investigación corrobora: primero, que un porcentaje abrumadoramente mayoritario de las víctimas se produjo en situaciones en las que la intervención policial no desencadenó la violencia; y segundo, que en varias localidades donde hubo altercados más graves, con asaltos a sedes derechistas y lerrouxistas o ataques a edificios religiosos, todo eso ocurrió sin que mediara intervención policial previa, al contrario, en algunos casos ante la pasividad de las fuerzas del orden. Como señaló un editorial de un periódico republicano de centro, si bien el nuevo Ejecutivo se formó apresuradamente por la presión de un posible estallido de desorden popular, finalmente la presión se desató en las calles de "inmediato» ${ }^{66}$. Azaña no quiso llegar tan pronto y en esas condiciones porque sabía, y no se equivocó, que tendría que afrontar «un desordenado empuje» que para algunos implicaba un uso deliberado de la violencia para exigir la inmediata adopción de medidas que iban más allá de la literalidad del pacto del Frente Popular y suponían un abierto desafío al Estado de derecho en pleno proceso electoral.

\section{Bibliografía}

Alcalá-Zamora, N. (2011). Asalto a la República. Enero-abril de 1936. Madrid: Esfera de los Libros.

Álvarez Tardío, M. (2012). Democratización y violencia política en el mundo de entreguerras: una cuestión abierta. Ayer, 88 (4), 27-49.

- (2013). The impact of political violence during the Spanish General Election of 1936. Journal of Contemporary History, 48 (3), 463-485. Disponible en: https://doi. org/10.1177/0022009413481823.

Aróstegui, J. (1994). Violencia, sociedad y política: la definición de la violencia. Ayer, 13.

Avilés Farré, J. (2006). La izquierda burguesa y la tragedia de la II República. Madrid: Comunidad de Madrid.

Ayala Vicente, F. (2003). La violencia politica en la provincia de Cáceres durante la Segunda República (1931-1936). Brenes: Muñoz Moya Editores Extremeños.

Azaña, M. (1981). Memorias. Volumen II. Barcelona: Crítica.

Barragán-Lancharro, A. M. (2006). Antecedentes de la guerra civil en la provincia de Badajoz: violencia política tras las elecciones de febrero de 1936. En F. Lorenzana de la Puente y F. J. Mateos Ascacíbar (coords.). Arte, poder y sociedad y otros estudios sobre Extremadura (pp. 293-310). Badajoz.

Blaney Jr., G. (2005). La historiografía sobre la Guardia Civil. Crítica y propuestas de investigación. Política y Sociedad, 42 (3), 31-44.

66 Ahora, 20-2-1936. 
- (2007). Keeping order in Republican Spain, 1931-1936. En Policing Interwar Europe: Continuity, Change and Crisis, 1918-1940 (pp. 31-68). Basingstoke; New York: Palgrave-Macmillan. Disponible en: https://doi.org/10.1057/9780230599864_3.

Blázquez Miguel, J. (2009). España turbulenta. Alteraciones, violencia y sangre durante la II República. Madrid: Tomás Pérez.

Botz, G. (1982). Political violence, its forms and strategies in the First Austrian Republic. En W. Mommsen y G. Hirschfeld (eds.). Social protest, violence, and terror in nineteenth and twenty century Europe (pp. 300-329). New York: St Martin's Press. Disponible en: https://doi.org/10.1007/978-1-349-16941-2_18.

Carmona Obrero, F. J. (2011). El orden público en Sevilla durante la II República (1931-1936). Sevilla: Patronato del Real Alcázar.

Chaves Palacios, J. (2000). Violencia politica y conflictividad en Extremadura: Cáceres en 1936. Cáceres: Diputación Provincial de Cáceres.

Cibrián, R. (1978). Violencia política y crisis democrática: España en 1936. Revista de Estudios Politicos, 6, 81-115.

Conteh-Morgan, E. (2003). Collective political violence: an introduction to the theories and cases of violent conflicts. London: Routledge.

Córdoba, C. (2011). De cada cuatro cayeron tres. Persecución y muerte de la Falange fundacional. Madrid: Ediciones Barbarroja.

Cruz, R. (2006). En el nombre del pueblo. República, rebelión y guerra en la España de 1936. Madrid: Siglo XXI.

Della Porta, D. (2006). Social movements, political violence, and the State. A comparative analysis of Italy and Germany. Cambridge: Cambridge University Press.

Durgan, A. (1996). BOC 1930-1936: el bloque obrero y campesino. Barcelona: Laertes.

Gil Andrés, C. (2006). Lejos del frente: la guerra civil en La Rioja Alta. Barcelona: Crítica.

Gil-Robles, J. M. (2006). No fue posible la paz. Barcelona: Ariel.

González Calleja, E. (2015). Cifras cruentas. Las víctimas mortales de la violencia sociopolitica en la Segunda República española. Granada: Comares.

Graham, H. D. y Gurr, T. R. (eds.) (1983). Violence in America. Vol. 2. Historical and Comparative Perspectives. New York: Chelsea House.

Ibarruri, D. (1984). Memorias de Pasionaria, 1939-1977. Barcelona: Planeta.

Juliá, S. (1977). La izquierda del PSOE (1935-1936). Madrid: Siglo XXI.

- (1979). Orígenes del Frente Popular en España. Madrid: Siglo XXI.

- (2008). Vida y tiempo de Manuel Azaña (1880-1940). Madrid: Taurus.

Kalyvas, S. (2010). La lógica de la violencia en la Guerra civil. Madrid: Akal.

Linz, J. J. (1996). La quiebra de las democracias. Madrid: Alianza.

Macarro, J. M. (2000). Socialismo, República y Revolución en Andalucía (1931-1936). Sevilla: Universidad.

Mann, M. (2004). Fascists. New York: Cambridge University Press. Disponible en: https://doi. org/10.1017/CBO9780511806568.

Martínez Barrio, D. (1983). Memorias. Barcelona: Planeta.

Martínez Leal, J. (2005). Los socialistas en acción: la II República en Elche (1931-1936). Alicante: Universidad de Alicante. 
Mommsen, W. y Hirschfeld, G. (1982). Social protest, violence, and terror in nineteenth and twenty century Europe. New York: St Martin's Press. Disponible en: https://doi. org/10.1007/978-1-349-16941-2.

Moreno Gómez, F. (1983). La República y la Guerra Civil en Córdoba. Córdoba: Ayuntamiento de Córdoba.

Nieburg, H. L. (1969). Political violence: The behavioral process. New York: St. Martin's Press.

Palacios, D. (2011). Ansias de normalidad. La policía y la República. En F. del Rey (dir.). Palabras como puños. La intransigencia política en la Segunda República Española (pp. 596-646). Madrid: Tecnos.

Payne, S. G. (1985). Falange. Historia del fascismo español. Madrid: Sarpe.

- (1990). Political violence during the Spanish Second Republic. Journal of Contemporary History, 25 (2-3), 269-288. Disponible en: https://doi.org/10.1177/00220094900 2500206.

- (2005). El colapso de la República. Los orígenes de la Guerra Civil (1933-1936). Madrid: La Esfera de los Libros.

Portela Valladares, M. (1988). Memorias. Dentro del drama español. Madrid: Alianza Editorial. Pulido Pérez, A. M. (2008). La Guardia Civil ante el bienio Azañista, 1931-33. Madrid: Almena.

Ranzato, G. (2006). El eclipse de la democracia. La guerra civil española y sus orígenes, $1931-$ 1939. Madrid: Siglo XXI.

- (2014). El gran miedo de 1936. Cómo España se precipitó en la guerra civil. Madrid: Esfera de los Libros.

Requena Gallego, M. (2006). Yeste durante la II República: modernización política y conflictividad social, 1931-1936. Albacete: Instituto de Estudios Albacetenses.

Rey Reguillo, F. del (2007). Reflexiones sobre la violencia política en la Segunda República española. En M. Gutiérrez y D. Palacios (eds.). Conflicto político, democracia y dictadura. Portugal y España en la década de 1930 (pp. 17-98). Madrid: CEPC.

- (2008). Paisanos en lucha. Exclusión política y violencia en la Segunda República española. Madrid: Biblioteca Nueva.

- (2011). Introducción. En F. del Rey (dir.). Palabras como puños. La intransigencia politica en la Segunda República Española (pp. 17-44). Madrid: Tecnos.

Sanz Hoya, J. (2006). De la Restauración a la reacción. Las derechas frente a la Segunda República (Cantabria, 1931-1936). Santander: Universidad de Cantabria.

Sepúlveda Losa, R. M. (2003). La primavera conflictiva de 1936 en Albacete. Pasado y Memoria, 2, 221-240. Disponible en: https://doi.org/10.14198/PASADO2003.2.09.

Souto Kustrín, S. (2004). «Y ¿Madrid? ¿Qué hace Madrid?». Movimiento revolucionario y acción colectiva (1933-1936). Madrid: Siglo XXI.

Tilly, Ch. (2007). Violencia colectiva. Barcelona: Hacer Editorial.

Tusell, J. (1971). Las elecciones del Frente Popular. Madrid: Edicusa.

- y Calvo, J. (1991). Giménez Fernández, precursor de la democracia española. Madrid: Mondadori.

Ugarte Pérez, J. y González, M. J. (2016). Juan Pablo Fusi. El historiador y su tiempo. Barcelona: Taurus.

Vaquero Martínez, S. (2016). De la ebullición a la contrarrevolución. Los significados del orden público en los libros de los gobernantes de la Segunda República española, 
1931-1936. Espacio, tiempo y forma. Serie V, Historia contemporánea, 28, 187-213. Disponible en: https://doi.org/10.5944/etfv.28.2016.16153.

Vega Gonzalo, F. de Asís de la (1999). Aniquilar la Falange. Cronología persecutoria del Nacionalsocialismo. Oviedo: Ediciones TARFE.

Von Der Mehden, F. R. (1973). Comparative political violence. New York: Prentice-Hall.

Zamora Caro, J. A. (2010). Palma del Río 1931-1936: la Segunda República en sus personajes y hechos. En J. L. Casas Sánchez y F. Durán Alcalá (eds.). El republicanismo ante la crisis de la democracia. Una perspectiva comparada (1909-1939) (pp. 561-573). Córdoba: Diputación Provincial de Córdoba. 